\title{
A KIÉGÉS VIZSGÁLATA \\ A MUNKAHELYI ELÉGEDETTSÉG, A SZERVEZETI ELKÖTELEZETTSÉG ÉS A MOTIVÁCIÓ FÜGGVÉNYÉBEN ORVOSOK KÖRÉBEN
}

\author{
Szerző: \\ Vladár Anita \\ Debreceni Egyetem
}

Szerző e-mail címe:

vladar.anita@gmail.com

\author{
Lektorok:
}

Csukonyi Csilla

Debreceni Egyetem

Papp Gábor

Debreceni Egyetem

Mező Ferenc

Debreceni Egyetem

Nemes Magdolna

Debreceni Egyetem

Vladár Anita (2016): A kiégés vizsgálata a munkahelyi elégedettség, a szervezeti elkötelezettség és a motiváció függvényében orvosok körében. Különleges Bánásmód, II. évf., 2016/3. szám, 15-29. DOI 10.18458/KB.2016.3.15

\begin{abstract}
Absztrakt
Jelen tanulmány arra a kérdésre keresi a választ, hogy az orvosok milyen kiégési értékekkel rendelkeznek, és ezek milyen összefüggésben állnak az esetükben mért munkahelyi elégedettséggel, szervezeti elkötelezettséggel és motivációval. Vajon az az orvos, aki elégedett a munkájával, elkötelezett a szervezet iránt és megfelelö motivációs szinttel rendelkezik, valóban alacsonyabb kiégési értékeket fog mutatni? Milyen lehet az összefüggés e három tényező között? Különbözö szakterületen dolgozó orvosok különböző értékeket fognak mutatni? Kutatásunkban négy csoportot vizsgáltunk: belgyógyászok, háziorvosok/házi gyermekorvosok, traumatológusok és pszichiáterek csoportját. Az eltérö típusú munka és betegszám elég okot adhat a különbségekre. Vizsgáltuk az életkor, a nem és az ügyelet vállalásának befolyását a kiégés szindróma kialakulására.
\end{abstract}

Kulcsszavak: kiégés szindróma, elégedettség, elkötelezettség, motiváció

Diszciplinák: társadalomtudomány, szociálpszichológia

\begin{abstract}
RESEARCH OF BURN-OUT WORK SATISFACTION DEPENDING ON

ORGANIZATIONAL COMMITMENT AND MOTIVATION AMONG DOCTORS

The aim of this study is to measure the level of the burnout of the doctors asked and to find what connections it has with job satisfaction, the commitment of employees and motivation. We wonder if a doctor who is satisfied with his work, committed to his organisation and has a proper motivation level, is less burnout? What can be the connection among these three factors? Can it be suppposed that the doctors with different specializations will have different results? We have conducted a research on four special groups: the research of internists, GP
\end{abstract}


(General Practitioners), traumaologists and psychiatrists. The different type of works and the different number of patients can be good reasons for getting different results. Moreover, we would like to know what influence age, sex, and being on duty have on the development of burnout syndrome.

Keywords: burnout syndrome, satisfaction, commitment, motivation

Disciplines: social sciences, social psychology

A 21. század orvoslásának egyik legnagyobb kihívást okozó probléma a kiégés szindróma, mely a munkavégzéssel kapcsolatos betegség. A jelenséggel csak az 1970-es években kezdtek el foglalkozni, Herbert J. Freudenberger német pszichoanalitikus írta le elöször. Főleg segítő szakmákban jelenik meg, pedagógusoknál, ügyfélszolgálati és egészségügyi dolgozóknál, tehát olyan szakmákban, ahol a dolgozók más emberek problémáival foglalkoznak, de előfordulhat jogászoknál vagy politikusoknál is. A kiégés oka valószínüleg a hosszú ideig fennálló, krónikus, folyamatos munkahelyi stressz, ami kimerültségen, deperszonalizáción, valamint csökkent elégedettségen alapulhat. A kiégett személy mentálisan, érzelmileg és fizikálisan is kimerült, gátolttá válik a munkavégzésben (Ónody, 2001).

Az orvosok különösen veszélyeztetett csoportot alkotnak a kiégés szindróma szempontjából. A kiégett orvos kevésbé érdeklődik a betegek állapota iránt, megkérdőjelezi a saját szakmai kompetenciáját és tudását, kevésbé élvezi a munkáját, fáradékonnyá, dekoncentrálttá és stresszessé válhat. Nemcsak a munkahelyén viselkedhet szarkasztikusan és kritikusan, hanem élete egyéb területein is. Azért különösen fontos az orvosok kiégésére kitüntetett figyelmet szentelni, mert esetükben egy hiba akár végzetes következményekkel is járhat, így nem engedhetik meg maguknak a kiégés bizonyos fázisaival járó nagyobb hibázás valószínüséget. Orvosnak lenni nemcsak mentálisan megterhelö, hanem érzelmileg és fizikailag is; a kiégés szindróma pedig mind a három területen erösebb terheléseket eredményezhet (Kopp és Berghammer, 2005).

Ennek ellenére az orvosi társadalom a kutatások alapján nagyobb kiégési értékekkel rendelkezik, mint a normál lakosság, a magyar orvosok esetében pedig ez különösen igaz. Egy elővizsgálat elvégzése alapján valószínűsíthető, hogy ebben többek között az alacsony fizetés, a nem megfelelő munkakörülmények, a kiszámíthatatlan ügyeleti idő, a hosszú munkaidő, valamint a nem megfelelő társas közeg játszik szerepet.

A kiégést rengeteg tényező befolyásolhatja, ilyen a munkával való elégedettség, a szervezeti elkötelezettség és a motiváció is. Ezzel a három jelenséggel valószínüleg csökkenthetők a kiégési értékek. Bizonyos vizsgálatok szerint az az orvos, aki elégedett a munkájával, elkötelezett a munkahelye iránt és megfelelö motivációs szinttel rendelkezik, sokkal alacsonyabb kiégési értékeket fog mutatni, míg az elégedetlenség, a motiválatlanság és alacsony elkötelezettség növeli az értékeket. Mindhárom említett tényezöt sok-sok más tényezö is befolyásolhat. Társadalmunk közös érdeke, hogy orvosaink ne legyenek kiégettek és örömmel végezzék a munkájukat.

\section{Témafelvetés}

Jelen tanulmány célja kideríteni, hogy az általunk vizsgált orvosok milyen kiégési értékekkel rendelkeznek, és ezek milyen összefüggésben állnak az esetükben mért munkahelyi elégedettséggel, szervezeti elkötelezettséggel és motivációval. Vajon az az orvos, aki elégedett a munkájával, elkötelezett a szervezet iránt és megfelelő motivációs szinttel 
rendelkezik, valóban alacsonyabb kiégési értékeket fog mutatni? Milyen lehet az összefüggés e három tényező között? Különbözö szakterületen dolgozó orvosok különböző értékeket fognak mutatni? Kutatásunkban négy csoportot vizsgáltunk - ezek: belgyógyászok, háziorvosok/házi gyermekorvosok, traumatológusok és pszichiáterek. Az eltérő típusú munka és betegszám elég okot adhat a különbségekre. Az életkor, a nem és az ügyelet vállalásának hatását is vizsgáltuk a kiégés szindróma kialakulása szempontjából.

\section{Az orvosi pálya megpróbáltatásai}

Amikor valaki úgy dönt, hogy orvosi tanulmányokba kezd, nagyon komoly elköteleződést vállal, hiszen nem csak szakmát, hanem életmódot és hivatást is választ. Már az egyetemi felvételi is jelentős stresszhelyzetnek számít, emellett a képzés két felében eltérő nehézségek jelentkeznek, illetve a klinikai gyakorlatban eltöltött évek során is (Shaw, Wedding, Zeldow és Diehl, 2001, idézi Kopp és Berghammer, 2003). Többek között az időnyomás és a kudarctól való félelem szerepel a stresszorok listáján. A szoros időbeosztás megszervezése újszerü feladatként jelentkezhet a hallgatók életében, ha életük minden területére szeretnének elegendő időt fordítani. Emiatt fontossági sorrend felállítása válik szükségessé. A kudarctól való félelem pedig az esetek nagy többségében azért jelentkezik, mert a középiskolásként kiválóan teljesítő diákok az egyetemen azzal szembesülnek, hogy sokkal erősebb teljesítményt kell nyújtaniuk azért, hogy hasonlóan eredményesen végezzék el az egyetemet. A klinikai évek során a csapatmunka nehézségeit kell elsajátítani, miközben a hierarchia alján helyezkednek el. Az emiatt kialakuló konfliktusok az egészségügyi személyzet és a hallgató között egy olyan stresszor, amire még nincsenek eléggé felkészülve a hallgatók. Emellett megnövekedik a hallgatókban a feszültség a hirtelen érkező hatalmas felelősség révén (Kopp és Berghammer, 2003).

Ahhoz, hogy az orvosok képesek legyenek ellenállni ezeknek a stresszoroknak, és a későbbiekben lehetőségük legyen a szakmabeli érvényesülésre, szükség van bizonyos alapvető kompetenciákra és képességekre. Ezeknek a kompetenciáknak köszönhetően az 1900-as évektől az orvoslás soha nem látott eredményeket ért el - alapvetően nőtt az átlagéletkor, többek között a fertőző betegségek előfordulásának csökkentésével -, ennek ellenére az orvosokkal és az orvoslással való elégedetlenség gyakorta kifejezésre kerül a betegek részéről. Emiatt is nagyon fontos megőrizni az orvos lelki egészségét. Az orvosi pszichológia alapvetően a szomatikus és pszichológiai kezelési módok integrálása és bemutatása, emellett fontos eszköz lehet az orvosok lelki és mentális egészségének a megőrzésében is. Az orvosi pszichológia szorosan összefügg az orvosi kommunikációval is, mivel a gyakorló orvos élete során több százezer pácienssel találkozhat, és nem megfelelö lelki egészség esetén a találkozás frusztrálóvá válhat. Továbbá a betegek kezelése során is segítséget jelenthet az orvosi pszichológia elsajátítása (Kopp és Berghammer, 2003).

Az orvosok között elöforduló leggyakoribb mentális betegségek közé tartozik a depresszió, az öngyilkosság - ez a második leggyakoribb halálok a balesetek után - és a különféle addikciók. A női hallgatókra és orvosnőkre jellemző a stressz és az öngyilkosság magas kockázata. Az öngyilkosság esélyét bizonyos személyiségtényezők növelhetik, mint a depresszió, az ellenségesség, a negativizmus, a gyanakvás, a dependencia és az impulzivitás. Emellett hozzájárulhat az elkövetéséhez a merev személyiség, az időgazdálkodás zavarai, a perfekcionizmus és az omnipotencia. Háttértényezők is befolyással lehetnek az öngyilkosság valószínüségére, például a vezetési stílus, a munkaidő hossza, az ügyelet, az alvásmegvonás és az ellenséges légkör. Mindemellett az egészségügyben dolgozókra, így az orvosokra is különösen nagy veszélyt jelent a kiégés (burnout) szindróma, melyről az alábbiakban 
olvashatunk. A gyakorló orvosok körülbelül 10-20\%-a betegszik meg valamely pszichiátriai zavarban (Kopp és Berghammer, 2005).

\section{A kiégés szindróma}

Eredetileg a burnout, azaz a kiégés a technológiában használatos fogalom, mellyel az energia-forrás gyengülésének a folyamatát szeretnék leírni egészen a megsemmisülésig. Fontos kiemelni, hogy ez a fogalom folyamatot jelöl - tehát egy folyamatos, több szakaszból álló formát, mely visszafordítható -, nem pedig végső állapotot, melyet burned-out címszóval említhetnénk (Ónody, 2001).

A fogalmat Herbert J. Freudenberger (1974) német születésü amerikai pszichoanalitikus írta le elöször. Főként emberekkel foglalkozó munkatípusoknál - önsegítő csoportokban, krízisintervenciós és egészségügyi intézmények dolgozóinál - vizsgálta a kiégés problémakörét. Herbert munkássága óta többen is kutatták a burnout szindrómát, ezáltal egyre több adatot találhatunk mind elméleti, mind gyakorlati szociálpszichológiai megközelítésben (Freudenberger, 1974; Ónody, 2001).

A burnout szindrómát a BNO-10 (2006) a betegségek közé sorolja a z73 kategóriába. Ez a kategória azokat a betegségeket foglalja magába, melyek az életirányítással és az önmenedzsment problémáival kapcsolatosak, mint amilyen a stressz és a szociális szerepzavar (BNO 10, 2006). A burnout szindróma a kimerültségen, a deperszonalizáción és a teljesítménnyel való csökkent elégedettségen alapszik. Legtöbb esetben a krónikus stressz következtében alakul ki. Az ápolói és a szociális munkakörök esetében fedezhetjük fel, többek között szociális munkásoknál, tanároknál és pedagógusoknál, nővéreknél, orvosoknál és fogorvosoknál (Weber és Jaekel-Reinhard, 2000).

Kopp és Berghammer (2003) a kiégés szindrómának öt fő tünetcsoportját különböztette meg:

- affektív (például érzelmi kimerülés),

- kognitív (például koncentrációs zavarok),

- testi-fizika (például fejfájás, táplálkozási zavarok),

- viselkedéses (például csökkent munkateljesítmény),

- motivációs (például a célok elvesztése, elszemélytelenedés) (Kopp és Berghammer, 2003).

Egyes becslések szerint az orvosok 30-40\%-nál megjelenik a kiégés szindróma olyan szinten, hogy az már befolyásolhatja nem csak a szakmai teljesítményt, de a személyes viselkedésüket is (WHO, 2000). Linzer és munkatársai 2001-ben 5700 orvost vizsgáltak meg. Az eredményekből kiderült, hogy a kiégési szindróma gyakorisága az Egyesült Államokban tevékenykedő orvosok körében 22 százalékos volt. Hollandiában 2400 orvost vizsgáltak, akiknek 11 százalékánál diagnosztizálták a szindrómát. Whippen és Canellos 1991-ben az egyesült államokbeli onkológusok 56 százalékánál tapasztalt kiégést (Linzer, Visser, Oort és mts., 2001; Whippen és Canellos, 1991) .

A kiégés nem csak a finn orvosok körében számít gyakorinak, hanem alapvetően az egész orvostársadalomban. Amerikában, Hollandiában, Angliában és Olaszországban mind 20-30\% között van a kiégésben szenvedő orvosok aránya (Major, Ress, Hulesch és Túry, 2006). A magyarországi orvosok között Györffy és Girasek (2015) végzett reprezentatív felmérést, ahol közel 5000 orvost vizsgáltak. Arra jutottak, hogy az orvosok 65\%-a érzi, hogy vesztett teljesítményéből és 49\%-a, hogy érzelmileg kimerült.

A szakorvosok között kevésbé jellemző a kiégés, mint a szakvizsgával nem rendelkezők között. Általában azokat említik veszélyeztetettebbnek, akik rendszerint halálos vagy gyógyíthatatlan betegségekkel foglalkoznak. Továbbá a női orvosok kiégése is gyakoribb, és nagyobb a hajlandóság a depresszióra, valamint az öngyilkosságra is. Ennek valószínüleg a 
szerepkonfliktus lehet az oka, mely az orvosi szakmát a családanya szereppel állítja szembe (Győrffy és Ádám, 2004; Győrffy és Girasek, 2015).

Győrffy és Girasek (2015) vizsgálatában a fiatal orvosok, a rezidensek és a fekvőbetegellátásban dolgozók értek el magas értékeket a kiégés dimenzióiban. Az ügyeleti munkavégzés és a párhuzamosan több munkahely vállalása is szoros összefüggéseket mutat a kiégéssel.

\section{Néhány befolyásoló tényezö}

A kiégés szindróma egyik befolyásoló tényezője lehet a munkahelyi elégedettség. Krasz Katalin 2002-es publikációja szerint a kutatók kizárólag a személyes szükségletekhez kapcsolódó tényezőként gondoltak az elégedettségre, ebből pedig az következik, hogy az elégedettség a munkával járó haszon függvénye, mely hozzájárul a munkavállaló szükségleteinek a kielégítéséhez. Tehát amennyiben a munka lehetővé teszi a munkavállaló szükségleteinek a kielégítését, akkor elégedettségröl számol be, ha nem, akkor viszont elégedetlenségröl (Krasz, 2002; 2007). Feltételezhetjük, hogy nyilvánvaló a kapcsolat az elégedettség mértéke és bizonyos szervezeti jelenségek között, mint amilyen a hiányzás, a fluktuáció vagy a teljesítmény (Kun, 2002). Éppen ezért a szervezeteknek érdemes arra törekedniük, hogy a dolgozóik elégedettsége a lehető legnagyobb szintet érje el.

A kiégés kialakulására a szervezeti elkötelezettség is hatással lehet. Olyan hivatások esetén, ahol a munkavállaló közvetlen kapcsolatban van a fogyasztóval - ezáltal befolyásolja a szervezetről kialakult véleményt -, különösen fontos a dolgozóba való befektetés, mely révén emelkedhet a szolgáltatás minősége (Hallowell, 1996). Ilyen az orvosi hivatás is, mely során kiemelten lényeges a szervezeti elkötelezettség megléte. Magyarországon „általános vélemény, hogy a munkaadónak gazdasági érdeke a képzett és motivált munkavállalók megtartása, föleg olyan területeken, ahol nehezen pótolható a több év alatt megszerzett szaktudás. A vállalatok számára a családbarát hozzáállás tehát nem karitatív tevékenység, hanem olyan program, amelynek a gazdasági, pénzügyi megtérülésével is számolnak" (Borbíró, Juhász, Nagy és Pál, 2007, 61. o.). Az elkötelezettség megértésére számos elméleti modellt dolgoztak ki, például a cél-egybeesési elméletet, mely a humanisztikus pszichológia azon állítására lett alapozva, miszerint az emberek esszenciális tulajdonsága a célirányosság, melynek köszönhetően minden cselekedetünknek jól körülhatárolható célja és értelme van. A modell azt állítja, hogy amennyiben a munkavállaló céljai és a szervezeti célok azonosak, illetve, ha a saját célok megvalósíthatók a szervezeti keretek között, akkor a munkavállaló elkötelezett lesz a szervezet iránt. A szervezeti szocializáció során a munkavállalók megtapasztalják a szervezeti értékrendet, célokat és elvárásokat, továbbá képesek megállapítani, hogy mekkora az egyezés a saját értékrenddel. Amennyiben kicsi az egyezés, a dolgozó elégedett lesz (János, 2005).

Pines amerikai szociálpszichológus úgy gondolta, hogy a motiváció és a kiégés szindróma között ok-okozati összefüggésekre lelhetünk azon személyek esetében, akik segítö foglalkozásúak. Ennek bizonyítása érdekében elvégzett egy longitudinális vizsgálatot, mely során a következő tüneteket jegyezte le: krónikus fáradtság, fejfájás, alvászavar, emocionális kimerültség, negatív önértékelés, depresszió, szakmai inkompetencia érzése, reménytelenség érzése és csökkent produktivitás (Pines és Keinan, 2005). A szervezet számára az a kedvező, ha a dolgozóik motiváltak. A motiváció az, amely meghatározza, hogy az egyén energiája mekkora részét hajlandó a munkájába fektetni megfelelő körülmények között. Amennyiben a dolgozó megfelelően motivált, akkor jó teljesítményt lehet elérni, még gyengébb képességü dolgozó esetén is. Ennek tudatában már a munkaerő kiválasztásánál is figyelmet lehet fordítani az egyén képességei és személyisége mellett a motivációra, tehát a viselkedés hajtóerejére és okára (Csukonyi, 2002). A kutatásban használt motivációs szintet mérő 
kérdőív McClelland motivációs elméletén alapul, mely nagyobb hangsúlyt helyez a tanult szükségletekre a belső szükségletekkel szemben. A hatalom, a teljesítmény és a kapcsolatok iránti szükségletekkel próbálta magyarázni az emberek motivációs rendszerét. Kiemeli, hogy ezek a motívumok tanultak, és eltérő társadalmakban vagy eltérő fejlődési stádiumokban másmás jellemzőket mutathatnak. A Maslow-féle szükséglethierarchiával ellentétben nem számol be hierarchikus elrendeződésről. McClelland szerint mindhárom motiváció megtalálható minden emberben eltérő mintázattal, és mind fejleszthető különböző képzésekkel, tréningekkel (Csukonyi, 2002; Fodor, 2007).

\section{Kutatás bemutatása}

Vizsgálatunkban arra a kérdésre kerestük a választ, hogy vajon a vizsgált orvosok milyen mértékben vannak kiégve. Vajon a négy csoport - a belgyógyászok, a traumatológusok, a háziorvosok/házi gyermekorvosok és a pszichiáterek - eredményei között lesz-e kimutatható eltérés? Továbbá kérdés, hogy a munkahelyi elégedettség, a szervezeti elkötelezettség és a motiváció mutat-e bármilyen összefüggést a kiégés értékeivel. Vajon a nem, az életkor és az ügyelet befolyásolja-e a kiégés megjelenését? A hipotézisek a következők:

H1: A traumatológusok és a belgyógyászok érzelmileg kimerültebbek lesznek, mint a pszichiáterek és a háziorvosok.

H2: A háziorvosokat kevésbé érinti a deperszonalizáció problémája, mint a másik 3 orvoscsoportot.

H3: A pszichiáter szakorvosok és a traumatológusok a legérintettebbek a teljesítményvesztés dimenziójában.

H4: Az alacsony kiégési értékekkel rendelkező orvosok magas értékeket érnek el a motivációs teszten, az elégedettség teszten és az elkötelezettség teszten is.

H5: A női orvosok kiégési mutatói magasabbak lesznek, mint a férfiaké.

H6: A kiégési mutatók az életkor növekedésével arányosan nőnek.

H7: Az ügyeletet vállaló orvosok magasabb értékeket érnek el a kiégési teszten, mint az ügyeletet nem vállalók.

\section{A vizsgálati minta}

Eredetileg négy csoport kiégési értékeinek vizsgálata volt a cél, melyek a következők:

- Traumatológusok

- Belgyógyászok

- Pszichiáterek

- Háziorvosok és Házi gyermekorvosok

Azért ezekre a területekre esett a választás, mert ezen csoportok szakorvosai merőben eltérő körülmények között dolgoznak és eltérő betegszám jellemzi munkájukat. Többek között Győrffy és Girasek 2015-ös munkája miatt keltették fel ezek a csoportok a figyelmemet. Kutatásuk eredményéül azt kapták, hogy a belgyógyászok, a traumatológusok és a pszichiáterek magas kiégési mutatókkal rendelkeznek. Míg a traumatológusokra, pszichiáterekre és belgyógyászokra a kórházi körülmények jellemzők, addig a háziorvosok és házi gyermekorvosok inkább rendelőkben tevékenykednek. Az első három csoport szakorvosainak munkája során jóval több kollégával kell együtt dolgozniuk, míg a háziorvosok kisebb közösségek tagjai. A magas betegszám mind a négy csoportot jellemzi, ám a háziorvosoknak bizonyos időszakokban - például influenza idején - különösen magas betegszámmal kell megbirkóznia.

A kérdöívet összesen 140 fö töltötte ki, ebböl 63 traumatológus szakorvos, 39 háziorvos/házi gyermekorvos, 33 belgyógyász szakorvos és 5 pszichiáter, melynek a 
százalékos megoszlása az 1. ábrán látható. A pszichiáter szakorvosok csoportjából igen kisszámú minta érkezett, ezért ez a csoport csak azoknál a hipotéziseknél volt számításba vehető, ahol a kérdések nem szakterületspecifikusak.

\section{1. ábra: Szakterület szerinti megoszlás (forrás: a Szerzö)}

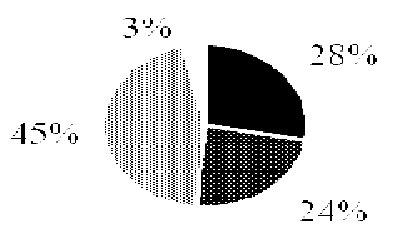

- IIazionosilazi gyenuekorvos

* Belgyógyisz

: Trammatologn:s

Pszichuáter

A nemek arányát tekintve jóval több férfi (89 fö, 63,6\%) válaszadó volt, mint női (51fö, 36,4\%). 26 éves kortól 73 éves korig oszlik meg a kitöltők életkora, a megoszlás a 2. ábrán látható.

2. ábra: A kitöltök kormegoszlása (forrás: a Szerzö)

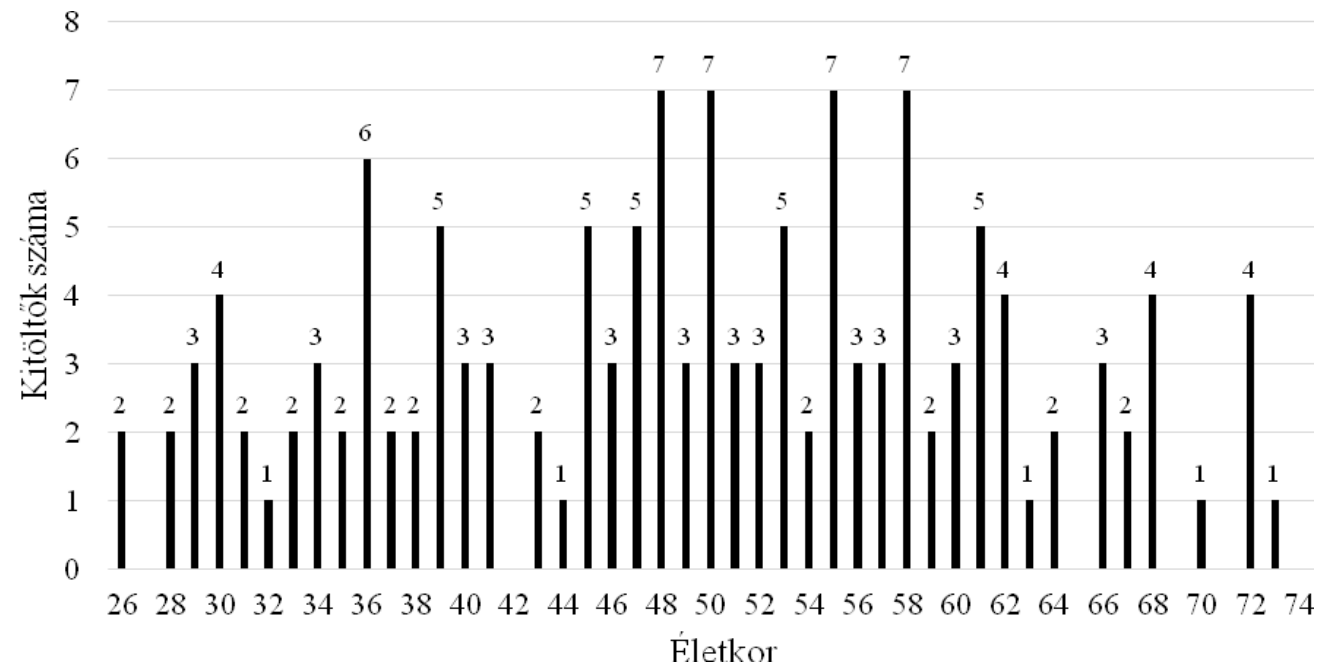

A következő egységek segítették a kutatási mintám összegyüjtését elektronikus formában:

- Semmelweis Egyetem Általános Orvostudományi Karának I. sz. Belgyógyászati Klinikája

- Magyar Traumatológus Társaság

- Kastélypark Klinika Kft.

- Házi Gyermekorvosok Országos Egyesülete

- Falusi Körzeti Orvosok Országos Szövetsége

- Magyar Orvosi Kamara Hajdú-Bihar Megyei Területi Szervezete

- A Debreceni Egyetem három tanszékéről papír alapon gyüjtöttem be a teszteket: 
- Debreceni Egyetem Családorvosi Tanszék

- Debreceni Egyetem Traumatológiai és Kézsebészeti Tanszék

- Debreceni Egyetem Pszichiátriai Tanszék

\section{Módszer}

A vizsgálati minta összegyüjtése önkitöltős kérdöív segítségével történt, kitöltése átlagosan 20 percet vett igénybe. A kérdöív öt kisebb kérdőívből áll, összesen 90 kérdést tartalmaz. A felhasznált kérdőívek a következők:

- Személyes adatok, demográfiai kérdőív

- Maslach Burnout Inventory kérdöív (MBI)

- Szervezeti elkötelezettség kérdőív (OCQ)

- Munkahelyi elégedettség kérdőív (MSQ)

- Diák Karrier Teszt (DKT)

\section{Személyes adatok, demográfiai kérdöív}

Ez a kérdőív a kutatás szempontjából releváns demográfiai és személyes változókra kérdez rá. Összesen 13, többnyire eldöntendő kérdéseket tartalmaz, ám bizonyos esetekben rövid válaszokat vár. Rákérdez az általános mutatókra - mint amilyen a nem, az életkor, a családi állapot, illetve a szakterület és a beosztás -, a jövőbeli, munkával kapcsolatos tervekre, továbbá az ideális munkahelyről való vélekedésre.

\section{Maslach Burnout Inventory (MBI) kérdöív}

A kiégés szindróma mérésére a Maslach nevével fémjelzett kérdőív a legáltalánosabban használt nemzetközileg elismert kérdőív (Maslach és Jackson, 1981). Jelentős áttörést jelentett a téma vizsgálatának történetében. Három dimenzió alapján méri a kiégési értékeket, melyek a következők (Maslach, Jackson és Leiter, 1996):

- Érzelmi kimerülés

- Deperszonalizáció

- Személyes teljesítmény és hatékonyság

Az érzelmi kimerülés a kiégés egyik legjellemzőbb tünete, mely szerint a kiégett személy úgy érzi, hogy érzelmi erőforrásai nap végére elfogynak. A deperszonalizáció a negatív és rideg hozzáállást jelez a pácienssel vagy kollégákkal szemben, emellett a kialakult helyzetért mások okolását. A harmadik dimenzió megmutatja, hogy az egyén az önmagától elvárthoz képest milyen szinten teljesít, mely negatív önértékelést idézhet elő (Tandari-Kovács, 2010).

A kérdőív 22 kérdést tartalmaz, mely elsősorban a segítő szakmákban dolgozók számára készült. A válaszadóknak egy hétfokú Likert-típusú skálán kellet jelölniük válaszaikat, mely szerint az 1-es érték jelentette, hogy egyáltalán nem jellemző rá egy állítás és a 7-es érték, hogy teljes mértékben jellemző.

Megalkotói a kiégést folyamatként értelmezik, értéke alacsonytól magasig terjedhet. Ha valaki magas pontszámot ér el az érzelmi kimerültség és a deperszonalizáció skálákon, és alacsony pontszámot a személyes hatékonyság skálán, az magas kiégettségről számolhat be (Maslach és Jackson, 1993; idézi Tandari-Kovács, 2010).

\section{Szervezeti elkötelezettség kérdöív (OCQ)}

A szervezeti elkötelezettség mérésére az OCQ, azaz az Organizational Commitment Questionire kérdőív magyar adaptációját alkalmaztam, melyet eredeti nyelven elsőként Porter és munkatársai dolgoztak ki, majd Meyer és Allen (1997) módosították. A kidolgozás során nagy hangsúlyt fektettek a Mowday és munkatársai által létrehozott rendszerre, mely a 
szervezeti elkötelezettség struktúráját próbálja definiálni. Ez a kérdőív a globális elkötelezettséget méri (Naser, 2007; Kanning és Hill, 2013).

Meyer és Allen háromkomponensü elkötelezettségelméletét számos ország kutatói vizsgálták, például Iverson és Buttigieg, Chang, Wastii és Mueller. Megerősítő faktoranalízis segítségével képesek voltak igazolni azt a feltételezést, hogy a háromfaktoros modell mutatja a legnagyobb egyezést az adatokkal (Naser, 2007).

A szervezeti elkötelezettség Meyer és Allen által meghatározott három komponensén affektív, normatív, folyamatos - alapul. A kérdöívben a következőképpen jelennek meg (Balogh, 2008):

(1) a szervezet céljaival és értékelésével való azonosulási képesség;

(2) a szervezetért tenni akarás megléte, a hajlandóság a cselekvésre a szervezet javára;

(3) a hosszú távú tagság iránti vágy.

A kérdőívet kitöltők ebben az esetben is egy hét fokozatú Likert-típusú skálán jelölhették a válaszaikat. 15 kérdést tartalmaz.

\section{Munkahelyi elégedettség kérdöív (MSQ)}

A Minnesotai Egyetem egyik kutatásához hoztak létre. Létezik rövidebb és hosszabb változata is, utóbbi 100 kérdést tartalmaz (Weiss, Davis és England, 1967). Lefedi a legtöbb munkával kapcsolatos értéket. A rövidebb változat többek között vizsgálja az önállóság, a stabilitás, a képességek felhasználása és a fizetés témakörét, és a dolgozók ezekkel kapcsolatban érzett elégedettségét (Kun, 2002). A kérdőív kitöltése során 20 kérdés esetében ötfokú Likert-skálán szükséges jelölni a válaszokat.

\section{Diák Karrier Teszt}

A Diák Karrier Teszt a teljesítménymotiváció feltárására ad lehetőséget. McClelland 1985ös motivációelméletén alapszik. Öt dimenzióra osztva vizsgálja az általános teljesítménymotivációt, a célra irányuló- és az elkerülő teljesítménymotivációt, illetve a hatalmi és a kötődési motivációt. Minden dimenzió vizsgálatára 4 kérdést tesz fel. Az általános teljesítménymotiváció azt a vágyat jelöli, hogy hatékonyak és eredményesek legyünk magunkhoz és másokhoz képest is. A teljesítménymotiváció vizsgálatakor figyelembe kell vennünk, hogy a motivációnk elkerülő vagy közelítő jellegü, ez alapján beszélhetünk célra irányuló és elkerülö teljesítménymotivációról. A hatalmi motiváció szintje megmutatja, hogy az egyén mennyire igényli a mások fölötti kontrollt, a presztízst, a pozíciót és a befolyást. A kötődési motiváció a kapcsolatok és a társaság iránti igényünket mutatja meg (Münnich, 2002).

\section{Feldolgozás}

A kérdőív segítségével szerzett adatok feldolgozása az SPSS statisztikai program használatával történt.

\section{Eredmények}

Az első három hipotézis vizsgálata párhuzamosan történt. Első lépésként ellenőriztük, hogy a kiégés három dimenziója a három csoporton belül normál eloszlást követ-e. Ehhez egymintás Kolmogorov-Smirnov próbát használtunk. Az eredmények azt mutatták, hogy a kiégés dimenziói nem követnek normál eloszlást $(\mathrm{p}<0,05)$, ezért a továbbiakban nem paraméteres statisztikai eljárásokat használtunk az elemzéshez. 
Kruskal-Wallis próbával néztük meg, hogy a csoportok között van-e szignifikáns különbség. Ezután a különbségek pontosabb meghatározása érdekében Mann-Whitney próbát végeztünk, mellyel lehetőség volt összehasonlítani párosával is a csoportokat.

Kruskal-Wallis próba alapján szignifikáns $(\mathrm{p}=0,01)$ különbséget találtunk a három vizsgált csoport között az Érzelmi kimerülésben. A háziorvosok medián értéke volt a legalacsonyabb (Medián = 23), ez szignifikánsan különbözött a belgyógyászokétól (Medián $=30, p=0,001$ ) és a traumatológusokétól (Medián $=31, \mathrm{p}=0,01$ ).

Szignifikáns $(\mathrm{p}=0,002)$ különbséget kaptunk a Deperszonalizáció szempontjából is. Ebben az esetben is a háziorvosok medián értéke a legalacsonyabb (Medián $=8$ ), és szignifikánsan eltér a belgyógyászokétól (Medián $=14, \mathrm{p}=0,001$ ) és a traumatológusokétól (Medián $=12, \mathrm{p}$ $=0,001)$.

Személyes hatékonyság szempontjából nem találtunk szignifikáns különbséget a három csoport között ( $\mathrm{p}=0,239)$, a mediánértékek is hasonlóak voltak: a háziorvosoké 38, ez nem sokban tért el a belgyógyászokétól (Medián $=36, \mathrm{p}=0,08$ ) és a traumatológusokétól (Medián $=36, \mathrm{p}=0,124)$.

Ezekből az eredményekből egyértelműen kiderül, hogy az Érzelmi kimerülés és a Deperszonalizáció dimenziók esetében szignifikáns különbség van a háziorvosok/házi gyermekorvosok és a másik két csoport között. Így az első és a második hipotézist (H1: A traumatológusok és a belgyógyászok érzelmileg kimerültebbek lesznek, mint a háziorvosok. $H 2$ : A háziorvosokat kevésbé érinti a deperszonalizáció problémája, mint a másik két orvoscsoportot.) igaznak tekinthetjük: valóban alacsonyabb kiégési értékekkel rendelkeznek a háziorvosok az Érzelmi kimerülés és a Deperszonalizáció dimenziók esetében, mint a traumatológusok és a belgyógyászok. A harmadik hipotézis (H3: A traumatológusok a legérintettebbek a Személyes hatékonyság dimenziójában.) kérdésében nem sikerült szignifikáns különbséget kimutatni a három csoport között, így a harmadik hipotézist nem sikerült igazolni.

A negyedik hipotézis szerint azok az orvosok, akik kevésbé kiégettek, magas értékeket fognak mutatni a munkahelyi elégedettség, a szervezeti elkötelezettség és a motiváció szempontjából is. A kérdés vizsgálata előtt végzett egymintás Kolmogorov-Smirnov-féle normalitásvizsgálat eredménye szerint a vizsgált változók nem normális eloszlásúak. A továbbiakban ezért Spearman-féle rangkorrelációs próbát alkalmaztunk a kapcsolatok vizsgálatára, melynek eredményeit az 1. táblázatban láthatjuk.

1. táblázat: Spearman-féle rangkorrelációk a változók között. Forrás: a Szerző.

\begin{tabular}{llll}
\hline \multirow{2}{*}{ Változó } & \multicolumn{3}{c}{ Maslach-féle kiégés kérdőív } \\
\cline { 2 - 4 } & $\begin{array}{l}\text { Érzelmi } \\
\text { kimerülés }\end{array}$ & $\begin{array}{l}\text { Deperszona- } \\
\text { lizáció }\end{array}$ & $\begin{array}{l}\text { Személyes } \\
\text { hatékonyság }\end{array}$ \\
\hline OCQ & $-0,457^{* *}$ & $-0,388^{* *}$ & $0,412^{* *}$ \\
MSQ & $-0,319^{* *}$ & $-0,357^{* *}$ & $0,469^{* *}$ \\
Általános teljesítménymotiváció & $-0,131$ & $-0,282^{* *}$ & $0,457^{* *}$ \\
Célra irányuló teljesítménymotiváció & $-0,194^{*}$ & $-0,307^{* *}$ & $0,295^{* *}$ \\
Elkerülő teljesítménymotiváció & $-0,167^{*}$ & $-0,254^{* *}$ & $0,233^{* *}$ \\
Hatalmi teljesítménymotiváció & $-0,152$ & $-0,098$ & $0,261^{* *}$ \\
Kötődési teljesítménymotiváció & $-0,046$ & $-0,132$ & $0,198^{*}$ \\
\hline
\end{tabular}

$* \mathbf{p} \leq \mathbf{0 , 0 5}$

$* * \quad \mathbf{p} \leq \mathbf{0 , 0 1}$ 
Általában véve gyenge, legfeljebb mérsékelt $\left(\left|\mathrm{r}_{\mathrm{s}}\right|=0,167\right.$ és 0,469 között) szignifikáns korrelációkat tapasztaltunk.

$\mathrm{Az}$ érzelmi kimerülés szempontjából igazolt a mérsékelt negatív korreláció 0,01-es szignifikancia-szinten a munkahelyi elégedettséggel és a szervezeti elkötelezettséggel, 0,05-ös szignifikanciaszinten pedig a célra irányuló és az elkerülő teljesítménymotivációval (ezek gyenge azonban gyenge kapcsolatok). Tehát azok az orvosok, akik alacsony pontszámot értek el a Maslach-féle kiégés kérdőív Érzelmi kiemerülés dimenziójában, azaz kevésbé kimerültek érzelmileg, elégedettebbek és elkötelezettebbek a munkahelyük iránt, és valószínübben magas célra irányuló és elkerülő teljesítménymotivációval rendelkeznek - $\mathrm{s}$ fordítva.

A Deperszonalizáció alskála szempontjából igazolásra került a mérsékelt negatív korreláció 0,01-es szignifikanciaszinten a munkahelyi elégedettséggel, a szervezeti elkötelezettséggel, az általános-, a célra irányuló- és az elkerülő teljesítménymotivációval is. Tehát akiket kevésbé érint a deperszonalizáció problémája, azok az orvosok valószínübben elégedettebbek, elkötelezettebbek a munkájuk iránt és magas a teljesítménymotivációjuk - s fordítva.

A Személyes hatékonyság pozitívan (de legjobb esetben is mérsékelt szinten) korrelál az összes vizsgált tényezővel, 0,01-es szinten a munkával való elégedettséggel, a szervezeti elkötelezettséggel, az általános-, a célra irányuló- és az elkerülő teljesítménymotivációval és a hatalmi motivációval, 0,05-ös szignifikanciaszinten a kötődési motivációval.

Az ötödik hipotézis szerint a női orvosok kiégési mutatói magasabbak, mint a férfi orvosoké. Tekintve, hogy a Kolmogorov-Sirnov próba szerint a változók nem normális eloszlásúak, így Mann-Whitney próbát alkalmaztunk. Nem sikerült szignifikáns különbséget kimutatni a két csoport között sem érzelmi kimerülésben $(\mathrm{p}=0,96$, Medián: nőknél $=25$, férfiaknál = 29), sem deperszonalizációban ( $\mathrm{p}=0,236$, Medián: nőknél = 10, férfiaknál =11), sem személyes hatékonyságban ( $\mathrm{p}=0,436$, Medián: nőknél $=37$, férfiaknál $=36$ ).

A hatodik hipotézis szerint az életkor növekedtével a kiégési értékek is nőnek. Az elvégzett Spearman-féle rangkorelációs vizsgálat releváns eredményeit az 5. táblázat összegzi.

5. táblázat: Az életkor és a kiégési mutatók összefüggése Spearman-féle rangkorreláció vizsgálatban. Forrás: a Szerző.

\begin{tabular}{clll}
\hline & & \multicolumn{2}{c}{ Maslach-féle kiégés kérdőív } \\
\cline { 2 - 4 } & Érzelmi kimerülés & Deperszonalizáció & Személyes hatékonyság \\
\hline \multirow{2}{*}{ Életkor } & $-0,224 * *$ & $-0,238^{* *}$ & $0,169^{*}$ \\
\hline$* \quad \mathbf{p} \leq \mathbf{0 , 0 5}$ & & & \\
$* * \mathbf{p} \leq \mathbf{0 , 0 1}$ & & &
\end{tabular}

Gyenge negatív korrelációt sikerült kimutatni az életkor és az Érzelmi kimerülés, valamint a Deperszonalizáció dimenziók között, és gyenge pozitív kapcsolat mutatkozott az életkor és a Személyes hatékonyság között. Az életkor elörehaladtával egyre kevésbé jellemző az érzelmi kimerülés és a deperszonalizáció az orvosoknál, míg a személyes hatékonyságot egyre jobbnak érzik. Ennek az lehet az oka, hogy a pályakezdő orvosok nagy lelkesedéssel és elvárásokkal rendelkeznek (Kopp és Berghammer, 2005), de hirtelen nagy mennyiségü 
stresszorral találkoznak, melyekkel szembe kell nézniük. Az idősebb orvosok megtanulják kezelni ezeket a stresszorokat, valószínüleg emiatt alacsonyabbak a kiégési mutatói. A hatodik hipotézist tehát nem sikerült igazolni, az eredmények szerint az ellenkezője igaz.

A hetedik, egyben utolsó hipotézist szintén Mann-Whitney próbával elemeztük, és szignifikáns különbséget találtunk az ügyeletet végzők és nem végzők között az Érzelmi kimerülés ( $\mathrm{p}=0,000$, Medián: ügyeletet végzőknél $=30$, nem végzőknél $=22)$ és a Deperszonalizáció ( $\mathrm{p}=0,001$, Medián: ügyeletet végzőknél $=12$, nem végzőknél $=8$ ) dimenziókban. Frekvenciaanalízis során kiderült, hogy az ügyeletet vállalók magasabb értékeket érnek el az előbb említett két dimenzióban. Személyes hatékonyság ( $\mathrm{p}=0,05$, Medián: ügyeletet végzőknél $=36$, nem végzőknél = 38) szempontjából nem tapasztalható különbség.

\section{Következtetések és javaslatok}

A tanulmány célja az volt, hogy megismerjük négy orvoscsoport kiégési mutatóit, és feltárja az összefüggéseket a kiégés és a munkahelyi elégedettség, a szervezeti elkötelezettség és a motiváció között. Hét hipotézist állítottunk fel, melyeket $n=140$ fös minta segítségével vizsgáltam.

Az eredmények többnyire igazolják a szakirodalmi bevezetőben állítottakat. Mint minden kutatási terület esetében, a pszichológiai kísérleteknek is fontos részlete a mintaszám méretének a megválasztása. Egyes kutatásokat 50\%-os eséllyel kudarcra ítélhet a kis minta választása, ha a méret meghatározása során téves, intuitív felfogás szerint döntünk. Az optimális méretet statisztikai programcsomagokkal elöre meg lehet határozni, így elkerülhetők az esetleges mütermékek (Cohen, 1962; Tversky, 1971).

Az első három hipotézis elemzése azonos statisztikai eljárással történt, melyek szerint az Érzelmi kimerülés és a Deperszonalizáció dimenzókban a háziorvosok és házi gyermekorvosok alacsonyabb pontszámokat értek el, mint a traumatológusok és a belgyógyászok, tehát a háziorvosok kevésbé kimerültek érzelmileg, és nem érinti őket olyan mértékben az elszemélytelenedés problémája, mint a belgyógyászokat és a traumatológusokat. Ez az eredmény leginkább arra vezethető vissza, hogy e három orvoscsoport merőben eltérö körülmények között végzik a munkájukat. A háziorvosok kevésbé stresszes légkörben dolgoznak, általában rendelőkben, kisebb munkacsoportban, míg a traumatológusok klinikai körülmények között nagyobb munkacsoport segítségével tevékenykednek. A háziorvosoknak kialakult betegkörük van, a pácienseikkel több évtizedes kapcsolatot is ápolhatnak, emiatt közelebbről is megismerheti egymást az orvos és a páciens, kisebb lesz a személytelenség közöttük. A traumatológusok és a belgyógyászok kevesebb személyes interakciót folytatnak egy beteggel, és korántsem biztos, hogy a jövőben újra találkoznak. A harmadik hipotézist nem sikerült igazolni, úgy tünik, hogy személyes hatékonyságukat hasonlónak ítélik meg az orvoscsoportok. Fontos kiemelni, hogy önkitöltős tesztekről van szó, tehát a kitöltő szubjektív véleményét ismerhetjük meg a kérdőív által.

A tanulmánynak szintén célja volt felderíteni, hogy vajon a munkahelyi elégedettség, a szervezeti elkötelezettség és az orvosok motivációs szintje milyen mértékben befolyásolja a kiégésüket, van-e közöttük bármilyen összefüggés. A várakozásoknak megfelelően sikerült igazolni az összefüggést a kiégés és az említett három tényező között. Azok az orvosok, akik alacsony kiégési mutatókkal rendelkeztek, elégedettebbek voltak a munkájukkal, elkötelezettebbek a munkahelyük iránt és magasabb motivációs szinttel rendelkeztek. Ezt az állítást érdemes fordítva is szemügyre venni: azok az orvosok, akik elégedettek a munkájukkal, elkötelezettek a munkahelyük iránt, és megfelelő motivációs szinttel rendelkeznek, kevésbé veszélyeztetettek a kiégés szempontjából. Mivel orvosaink megfelelö 
mentális és lelki egészsége közös érdekünk, úgy gondolom, hogy ezt minden munkáltatónak érdemes figyelembe vennie, mikor meghozzák a szervezettel kapcsolatos, orvosokat is érintő döntéseiket.

Összehasonlításra kerültek a női és a férfi orvosok kiégési mutatói. A szakirodalom alapján feltételezhető volt, hogy a női orvosok magasabb kiégési mutatókkal fognak rendelkezni, mivel felléphet náluk a szerepkonfliktus, mely szembe állítja az anyai szerepet az orvosi szakmával, ám ezt nem sikerült igazolni. Elképzelhető, hogy nagyobb számú minta esetén láthatóvá vált volna az eltérés a női és férfi kiégési értékek közt.

Hatodik hipotézisünk arra vonatkozott, hogy az életkor előrehaladtával növekedni fognak a kiégési mutatók is. Feltételeztük, hogy az orvosok idősebb korukra a pácienseket egyre inkább ,adatként” fogják kezelni, ennek alapját pedig az szolgáltatta, hogy a gyógyító tevékenységet folytató emberek, mint amilyenek az orvosok is, fokozottan veszélyeztetettek a kiégés szindróma szempontjából. A több évtizeden keresztül tartó folyamatos fizikai, mentális és lelki leterheltség, az állandó stressz és felelősség eredményezheti a kiégés kialakulását az idősebb orvosok esetében. Ezzel szemben ellenkező eredményt kaptunk: a kiégés szintje fordítottan arányos a korral, mind a három dimenzió esetében (Érzelmi kimerülés, Deperszonalizáció és Személyes teljesítmény és hatékonyság). Ennek az lehet az oka, hogy a fiatal orvosok nagy lendülettel, lelkesedéssel, és magas elvárásokkal érkeznek a szakmába, ám hirtelen velük szemben lesznek magasak az elvárások. Nagy felelősséggel és újszerü, nehéz feladatokkal kell szembenézniük. Kopp és Berghammer (2003, 2005) szerint már az egyetemi felvételi is jelentős stresszhelyzet, ám az egyetem és kezdetben a klinikai évek nehézségei folyamatosan megkövetelik az alkalmazkodást. Az alapvető kompetenciák elsajátítása hosszas folyamat, de feltétlenül szükséges ahhoz, hogy az orvosok képesek legyenek felvenni a harcot a kiégés szindrómával szemben.

Logikusnak tűnhet az utolsó hipotézis eredménye, miszerint az ügyeletet vállalók érzelmileg kimerültebbek, és deperszonalizáltabbak, mint azok az orvosok, akik nem vállalnak ügyeletet. Az ügyelet egy nagy mentális és fizikai megterhelést jelent, főleg, ha az orvos közvetlenül a munkája után végzi.

A kérdőív rákérdezett arra is, hogy milyen az ideális munkahely a kitöltők szerint. Rengeteg válasz érkezett, de volt néhány tényező, amit számos kitöltő említett. Legtöbb esetben a korrekt munkahelyi körülményeket és a megfelelő eszközhátteret emelték ki az orvosok, de ezen kívül sokszor fordult elő a stabilitás, a megbízhatóság, az elismerő légkör fontossága, a megfelelően magas jövedelem, presztízs, a szakmai kihívás, az önállóság, a nyugodt és barátságos, esetenként családias légkör, a vezető alkalmassága és a kiszámítható munkaidő és ügyelet. A háziorvosok és házi gyermekorvosok közül többen úgy gondolták, hogy az ideális munkahely olyan, mint a jelenlegi munkahelyük. Ezek olyan tényezők, amikre fontos lenne több figyelmet fordítani.

Szeretnénk a jövőben további kutatásokat végezni ebben a témakörben nagyobb mintával. Ennek érdekében helyet kapott a kérdöívben néhány kérdés, melyek érdekes vizsgálatokat tesznek lehetővé a későbbiekben. A családi állapot (ami nem csak a kiégés szindróma kialakulását befolyásolhatja, de a motivációra is hatással lehet) tekintetében nőknél és férfiaknál eltérő eredményekre számítunk. A szakmában eltöltött évek száma is fontos változó lehet, valamint érdekes lehet megvizsgálni azt is, hogy ebböl hány évet töltött a kitöltő a jelenlegi munkahelyén, illetve milyen beosztásban tevékenykedik. Sokat kideríthetünk abból is, hogy a válaszadó hány évre tervez a jelenlegi munkahelyén. Kérdés lehet az is, hogy a külföldi munkavállalás milyen hatással van a kiégési értékekre, illetve a kiégési értékek milyen hatással vannak a külföldi munkavállalási szándékra.

Manapság már számos tréning és technika létezik annak érdekében, hogy a kiégés szindróma veszélyét csökkentsék a dolgozóknál. Ezek nagyon fontosak, hiszen lényeges, 
hogy az orvost elkerülje a kiégés és megfelelő elégedettséggel, elkötelezettséggel és motivációval végezze a munkáját.

\section{Összefoglalás}

A kiégés szindróma a 21. század orvoslásának egyik legégetőbb problémája. Az orvosok különösen veszélyeztetett csoportot alkotnak a kiégés szempontjából, mely gátolja őket a munkavégzésükben. A kiégett orvos kevésbé érdeklődik a betegek állapota iránt, megkérdőjelezi a saját szakmai kompetenciáját és tudását, kevésbé élvezi a munkáját, fáradékonnyá, dekoncentrálttá és stresszessé válhat. Számos befolyásoló tényezője közül három változóra fektettünk nagyobb hangsúlyt e tanulmányban: a munkahelyi elégedettségre, a szervezeti elkötelezettségre és a motivációra.

E kutatási terület számos további vizsgálatra ad lehetőséget. Kérdőívünkben elhelyeztünk néhány kérdést a jövőre való tekintettel, melyeket szándékunkban áll egy következő vizsgálat keretében felhasználni.

\section{Irodalom}

Balogh, L. (2008): A teljesítményt befolyásoló szervezetpszichológiai tényezök vizsgálata interaktív sportcsapatoknál. Doktori értekezés. Pécsi Tudományegyetem Pszichológiai Doktori Iskola, Pécs.

BNO-10 (2006): Betegségek Nemzetközi Osztályozása: gyakori kódok betürendes mutatója. 10. revizió. Animula, Budapest.

Borbíró, F., Juhász, B., Nagy, B., Pál, K. (2007): Férfibeszéd - családról és munkáról. Fiatal Nőkért Alapítvány, Budapest.

Cohen, J. (1962): The Statistical Power of Abnormal-Social Psychological Research: A Review. J Abnorm Soc Psychol, 65, 145-53.

Cohen, J. (1962): The Statistical Power of Abnormal-Social Psychological Research: A Review. J Abnorm Soc Psychol, 65, 145-53.

Csukonyi, Cs. (2002): A motiváció alapelvei. In: Münnich Á. (szerk.): A jövő vezetöinek jelene. ELTE Eötvös Kiadó, Budapest.

Fodor, L. (2007): Fejezetek a motivációkutatásból. Gondolat Kiadó, Budapest.

Freudenberger, H.J. (1974): Staff Burn-out. Journal of Social Issues, 30, 159-175.

Győrffy, Z., Ádám, S. (2004): Az egészségi állapot, a munka-stressz és a kiégés alakulása az orvosi hivatásban. Szociológiai Szemle, 11, (3), 107-128.

Győrffy, Zs., Girasek, E. (2015): Kiégés a magyarországi orvosok körében. Kik a legveszélyeztetettebbek? Orvosi Hetilap, 156, (14), 564-570.

Hallowell, R. (1996): Southwest Airlines: A Case Study Linking Employee Needs Satisfaction and Organizational Capabilities to Competitive Advantage. Human Resource Management, 35, (4), 513-534.

János, R. (2005): Szervezetpszichológia. Oktatási segédanyag, Pécsi Tudományegyetem, Pécs. Kanning, U.P., Hill, A. (2013): Validation of the Organizational Commitment Questionnaire (OCQ) in six Languages. Journal of Business and Media Psychology 4, (2), 11-20.

Kopp, M., Berghammer, R. (2003): Orvosi pszichológia. Medicina, Budapest.

Kopp, M., Berghammer, R. (2005): Orvosi pszichológia. Medicina, Budapest.

Krasz, K. (2002): A munkahelyi elégedettség befolyásoló tényezök. Oktatási segédlet. Budapesti Múszaki és Gazdaságtudományi Egyetem, Ergonómia és Pszichológia Tanszék, Budapest. 
Krasz, K. (2007): Alapismeretek a vezetöi gyakorlathoz. Oktatási segédanyag, Budapesti Müszaki és Gazdaságtudományi Egyetem, Ergonómia és Pszichológia tanszék, Budapest.

Kun, Á. (2002): A munkával való elégedettség megismerésének elméleti és módszertani alapjai. In: Münnich Á. (szerk.): A jövő vezetöinek jelene. ELTE Eötvös Kiadó, Budapest.

Linzer, M., Visser, M.R., Oort, F.J. és mts. (2001): Predicting and preventing physician burnout: Results from the United States and the Netherlands. The American Journal of Medicine, 111, 170-175.

Major, J., Ress, K., Hulesh, B., Túry, F. (2006): A kiégés jelensége az orvosi hivatásban. Lege Artis Medicinae, 4, 367-373.

Maslach, C., Jackson, S.E. (1981): Maslach Burnout Inventory Manual. Consulting Psychologists Press, Palo Alto, California.

Maslach, C., Jackson, S.E. (1993): Maslach Burnout Inventory: Manual (2nd ed). Consulting Psychologist Press, Palo Alto, California.

Maslach, C., Jackson, S.E., Leiter, M.P. (1996). The Maslach Burnout Inventory (3rd ed.). Consulting Psychologists Press, Palo Alto, California.

Meyer, J., Allen, N. (1997): Commitment in the Workplace: Theory, Research, and Application. Sage Publications.

Münnich, Á. (2002): A jövő vezetőinek jelene: az egyetemi diákság karrierépítésének lélektani háttere. ELTE Eötvös Kiadó, Budapest.

Naser, S. (2007): Egyetemi oktatók szervezeti elkötelezettsége, és annak kapcsolata a szervezeti kultúrával. Magyar Pedagógia, 107, (3), 185-203.

Ónody, S. (2001): Kiégési tünetek (burnout szindróma) keletkezése és megoldási lehetőségei. Pedagógiai szemle, Május, 15-21.

Pines, A.M., Keinan, G. (2005): Stress and burnout: The significant difference. Personality and Individual Differences, 39, (3), 625-635.

Shaw, D.L., Wedding, D., Zeldow, P.B., Diehl, N. (2001): Special problems of medical students. In: Wedding, D. (szerk.): Behavior and medicine. Hogrefe and Huber, Göttingen, 67-84.

Tandari-Kovács, M. (2010). Érzelmi megterhelödés, lelki kiégés az egészségügyi dolgozók körében. Doktori (PhD) Értekezés, Semmelweis Egyetem, Budapest.

Tversky, A., Kahneman, D. (1971): Belief in the Law of Small Numbers. Psychological Bulletin, 76, 105-110.

Weber, A., Jaekel-Reinhard, A. (2000): Burnout Syndrome: A Disease of Modern Societies?. Occup Med (Lond) 50, (7), 512-517.

Weiss, D.J., Dawis, R.V., England, G.W. (1967): Manual for the Minnesota Satisfaction Questionnaire. Minnesota Studies in Vocational Rehabilitation, 22, 120.

Whippen, D.A., Canellos, G.P. (1991): Burnout syndrome in the practice of oncology: results of a random survey of 1,000 oncologists. J Clin Oncol, 9, (10), 1916-1920.

WHO-World Health Organization (2000): The World Health Report, 2000. Geneva. 